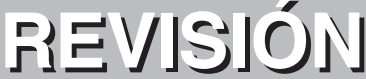

\section{Stearic acid: a possible substitute for trans fatty acids from industrial origin}

\author{
By Alfonso Valenzuela, ${ }^{1 *}$ Bernadette Delplanque $^{2}$ and Marcelo Tavella ${ }^{3}$
}

\author{
${ }^{1}$ Instituto de Nutrición y Tecnología de los Alimentos (INTA), Universidad de Chile, Santiago, Chile. \\ Facultad de Medicina, Universidad de los Andes, Santiago, Chile \\ ${ }^{2}$ Laboratoire de Neuroendocrinologie Moléculaire de la Prise Alimentaire (NMPA) UMR 1197, \\ Université Paris Sud, Orsay, France. \\ ${ }^{3}$ Programa de Prevención del Infarto en Argentina - INIBIOLP. Universidad Nacional \\ de La Plata, La Plata, Argentina. \\ ( ${ }^{*}$ Corresponding author: avalenzu @ inta.cl)
}

\section{RESUMEN}

El acido esteárico: un posible sustituto para los ácidos grasos trans de origen industrial.

Los isómeros trans que contienen los aceites parcialmente hidrogenados de origen industrial, han sido cuestionados y la recomendación es reducir su consumo. La industria de alimentos se enfrenta a un dilema, ya que para disminuir los isómeros trans debe reducir los aceites parcialmente hidrogenados y reemplazarlos por grasas ricas en ácidos grasos saturados. La investigación ha demostrado que los ácidos grasos saturados tienen efecto negativo en los lípidos plasmáticos y su consumo se asocia con un alto riesgo cardiovascular, por lo cual la recomendación es reducir el consumo de estos ácidos grasos. Sin embargo, no todos los ácidos grasos saturados se comportan de la misma forma, siendo el ácido esteárico (18:0) la excepción. El ácido esteárico presenta bajo nivel de absorción intestinal y no modifica negativamente los lípidos plasmáticos, por lo cual se considera como "neutro" para la salud cardiovascular. Los niveles plasmáticos de la apoproteína B-100, que determina las concentraciones de las VLDL y LDL (transportadoras de triglicéridos y colesterol, respectivamente) no son modificados por dietas que aportan hasta 7\% de la energía como ácido esteárico. Marcadores de riesgo cardiovascular, como la activación de factores de agregación plaquetaria o los niveles de la proteína $C$ reactiva, no son modificados por dietas que aportan ácido esteárico, como ocurre con otros ácidos grasos saturados. La confirmación del efecto "neutro" del ácido esteárico es una perspectiva para el desarrollo de grasas con alto contenido de este ácido graso para reemplazar las grasas hidrogenadas que contienen isómeros trans. Esta revisión discute estos aspectos.

PALABRAS-CLAVE: Ácido esteárico - Alternativa a las grasas hidrogenadas - Efecto metabólico neutro - Isómeros trans - Salud cardiovascular.

\section{SUMMARY}

Stearic acid: a possible substitute for trans fatty acids from industrial origin.

Trans isomers, contained in partially hydrogenated oils, which are used in the food industry, have been questioned and nowadays trends are heading towards reducing their consumption. The food industry is facing a dilemma, since in order to remove trans fatty acids, hydrogenated fats should be eliminated and replaced by fats rich in saturated fatty acids. Scientific research has shown that saturated fatty acids have negative effects on the lipid profile and its consumption is associated with a higher cardiovascular risk. Therefore it is recommended to avoid their consumption. Nevertheless, not all fatty acids behave in the same way, with stearic acid (18:0) the exception. Stearic acid has a low level of intestinal absorption and its intake does not negatively modify the lipid profile. For this reason, it is considered a "neutral" fatty acid with regard to cardiovascular health. B-100 apolipoprotein, whose levels determine plasma VLDL and LDL concentration (triglycerides and cholesterol carriers, respectively), is not modified by diets which provide up to $7 \%$ of the energy as stearic acid. Markers of cardiovascular risk, such as activation of platelet aggregation factors or $\mathrm{C}$-reactive protein levels, are not modified by diets providing stearic acid, as occurs with other saturated fatty acids. The confirmation of the "neutral" effect of stearic acid represents a perspective for the development of fats with high contents of this fatty acid to replace hydrogenated fats containing trans isomers. The present review discusses these aspects.

KEY-WORDS: Alternatives to hydrogenated fats Cardiovascular health - "Neutral" metabolic effect - Stearic acid - trans Isomers.

\section{INTRODUCTION}

The dietary consumption of fatty acids with trans isomerism (TFA) has been called into question by health and food authorities due to their adverse effects on overall health and mainly on cardiovascular health derived from their consumption (Ascherio et al., 1996; Hu et al., 1997; Hunter, 2006; Mozaffarian et al., 2009). Several epidemiological and clinical studies have unmistakably demonstrated that TFA acids produce an increase in plasmatic total cholesterol levels, in LDL-cholesterol levels (bad cholesterol) and in total triglycerides (Kris-Etherton et al., 2005; Mozaffarian et al., 2006; Hunter, 2006). 
It has been also demonstrated that TFA reduce HDL-cholesterol levels (good cholesterol) (Hu et al., 1997). There is also evidence that TFA can increase type 2 diabetes complications (Salmeron et al., 2001; Tanasescu et al., 2004; Saravanan et al., 2005). These effects have a negative incidence on health, for they increase in the risk of cardiovascular diseases, which are the main reason for death in the population of the western world. Nowadays, it is considered that the TFA negative effect on health can be at least compared with the effect of saturated fatty acids (SAFA) (Sundran et al., 1997; Hu et al., 1997; Valenzuela \& Morgado., 1999; Judd et al., 2002; Hunter, 2006). According to epidemiological studies and in order to avoid a possible incidence of cardiovascular risk, health authorities have proposed to limit TFA consumption to $2 \%$ of the total energy supply (US FDA, 2003; Uauy et al., 2009).

Different countries have adopted policies aiming at a drastic reduction in TFA consumption in their populations (Stender et al., 2006). Since June $1^{\text {st }} 2003$, Denmark has forbidden any content higher than $2 \%$ of TFA in both locally produced and imported fats hence the use of partially hydrogenated fats has been essentially eliminated from this country (Leth et al., 2005). Countries such as Norway, Finland, and the Netherlands have similar initiatives (Aro, 2005). Since 2003, Canada has become the first country in America to regulate the compulsory labelling of TFA and in 2006 it was proposed that TFA should not exceed $2 \%$ of the total fat content in vegetable oils and soft margarines for spread, and $5 \%$ of the total fat content in other foods. The United States introduced the compulsory labelling of TFA in 2006 (Eckel et al., 2007), an initiative that was followed by many other countries in Latin America, mainly MERCOSUR countries (Argentine, Brazil, Paraguay and Uruguay), and Chile (Valenzuela, 2008). Important fast food chains have withdrawn TFA from their products in different Latin American countries (Argentina, Brazil, Chile, Uruguay) (Valenzuela, 2008a). Most recently, the state of New York, in the United States, banned the use of hydrogenated products containing TFA in fast food restaurants. In response to these requirements, different industrial and fast food companies have announced the removal or future elimination of fats containing TFA in their products (Korver \& Katan, 2006; Mozaffarian \& Clarke, 2009).

In recent years, The World Health Organization (WHO) has held three meetings of Scientific Update on the elimination of TFA: PAHO (Pan American Health Organization) meeting, Washington DC, USA, August 2007; PAHO meeting, Washington, DC, USA, November 2007; and WHO meeting, in Geneva, Italy, February 2008. Their findings indicate that the replacement of TFA in partially hydrogenated vegetable oil with alternative fats and oils would substantially lower cardiovascular disease risk through multiple mechanisms beyond those on cholesterol-lipoprotein fractions (Kris-
Etherton et al., 2005), thus explaining in part the difference derived from estimates based on controlled dietary interventions focusing mainly on serum cholesterol fractions versus prospective cohort studies having cardiovascular disease events as their main outcome (Hunter et al., 2010). It is important to highlight that in Europe, the starting point was in the early 1990s, when the TFA reduction in certain margarines was implemented by means of suppressing partially hydrogenated fats (Morin, 2007). This situation has been envied by Americans and in 1994 Harvard researchers, lead by epidemiologist Walter Willett, encouraged people to join the European initiative (Ascherio et al., 1996). Willett's group urged Americans to stop eating TFA and encouraged the Food and Drug Administration (FDA) to add them to food labels, a step the agency considered (Ascherio et al., 1996). The same researchers also urged companies to follow Europe's lead in improving hydrogenation and producing margarine without TFA ( $\mathrm{Hu}$ et al., 1997). Most recent food surveys pointed out that TFA consumption had effectively decreased in several European countries mainly due to the reformulation of several food products, for example spreads (Korver \& Katan, 2006).

\section{TFA ISOMERS ORIGIN AND CONSUMPTION}

TFA isomers have two main origins: biological and technological (Valenzuela \& Morgado, 1999). Biological ones come from products derived from ruminant animals (beef, beef tallow, milk and its derived products), and they do not involve more than $5-10 \%$ of the total consumption of TFA isomers in European and American countries (Larqué et al., 2001). Therefore, in these countries TFA intake comes essentially from technological sources, (90$95 \%$ ) mainly hydrogenated fats, frying processes and to a lesser degree from edible oils which are treated with a deodorization process (Larqué et al., 2001; Craig-Schmidt, 2006). Current guidelines recommend an intake lower than $1 \%$ of the energy as TFA (Eckel et al., 2007). In the United States current consumption is around $2.5-3 \%$ of the total energy, meaning 5.8-6.0g/day (Allison et al., 1999), although it might reach $10 \mathrm{~g} /$ day or more in some segments of the population. Consumption in Latin America varies remarkably from country to country, but the average is around 4.5-5.0 g/day (Valenzuela, 2008a). Consumption in European countries varies depending on the country as well, but it is generally lower than in American countries, ranging from 1.4 to $5.0 \mathrm{~g} /$ day in a remarkable decreasing rate from North to South (higher in the North than in the South, eg: Netherlands vs Spain) (Kromhout et al., 1995; Hutshof et al., 1999). The TFA source is completely different in Europe. A great deal of TFA fat has animal origin (40 to $60 \%$ vs. 5 to $10 \%$ in the US), also with a significant decreasing rate from North to South. Animal products are the main 
source with $60 \%$; dairy products around $50 \%$ (butter $35 \%$ and cheese 17\%) and ruminants beef $10 \%$. Biscuits, pastry, industrial bakery and cooked dishes come next with 30-40\% (Husthof et al., 1999). An important issue to highlight is that the information gathered from countries that recently joined the European Union shows that Eastern European countries seem to have a much higher consumption than in Western Europe.

From the food industry point of view, it is very difficult to reduce the use of hydrogenated fats, the main source of TFA isomers, since these fats are essential for the manufacturing of several food products. Hydrogenated fats work as a base for adding other nutrients, they have thermal stability, they provide palatability and crispy characteristics to products, etc (Valenzuela \& Morgado, 1999; Korver \& Katan, 2006). In this way, it is currently a challenge for the food industry to substitute TFA present in their products without altering organoleptic characteristics such as appearance and stability. Within the few available alternatives to this possible replacement, the ones most commonly found are mainly oils with low polyunsaturated fatty acid contents, or with high SAFA contents (palm oil, high oleic sunflower oil, low linoleic soybean oil, etc.) (Tarragó-Trani et al., 2006). However, nowadays, stearic acid (C18:0) (STA) turns out to be a recent alternative with great significance (Hunter et al., 2010). How could an SAFA replace TFA isomers? The purpose of this review is to analyze the evidence of the neutral effects of STA in lipid and vascular parameters which constitute the markers of cardiovascular disease risk, and to state the reason why this fatty acid contained in fats can constitute a reasonable alternative for the substitution of TFA in our diet.

\section{STA, A "DIFFERENT" FATTY ACID}

STA is a saturated fatty acid present in fats of both animal and vegetal origin. Following palmitic acid (C16:0), it is the most widely consumed fatty acid in the United States as well as in the Western population in general (Ervin et al., 2004). Palmitic acid (16:0) amounts to $56 \%$ of the total consumption and stearic acid $26 \%$, approximately. The rest of the SFA consumption consists of myristic (C14:0), and lauric acid (C12:0), and in lower quantities butyric $(\mathrm{C} 4: 0)$, capric $(\mathrm{C} 10: 0)$, caproic $(\mathrm{C} 6: 0)$, and caprylic acid (C8:0). STA is taken from animal fat (bovine, porcine, ovine and marine fish), and in lower amounts from vegetable fats (coconut oil, soybean oil, corn oil, cocoa butter, etc). Figure 1 shows the STA contents in different fats of regular consumption.

Fatty acid absorption into the human digestive system essentially depends on the position that fatty acids have in dietary triglycerides (Mu \& Hǿy, 2004), which amount to $90-95 \%$ of our fat consumption. The rest of our intake consists of phospholipids (3.5-4\%), and different sterols $(1.5-2 \%)$, such as cholesterol, phytosterols, phytostanols, etc. (Carroll, 1958). In animal fats, SAFAs usually occupy $s n-1$ and $s n-3$ positions of triglycerides, and in a lower proportion they are found in the sn-2 position (Bracco, 1994). In bovine, porcine and ovine fats, STA is much more frequently found in the $s n-1$ and $s n-3$, than in the sn-2 position. In vegetable fats, SAFAs, especially STAs, mainly occupy the $s n-1$ and $s n-3$ positions of triglycerides as well (Mattson \& Volpenhein, 1964). The sn-2 Position of these fats and oils is frequently occupied by unsaturated fatty acids, such as oleic acid (C18:1) and less frequently by linoleic (C18:2),

\section{Ordinary Fatty Acids in Edible Fats and Oils}

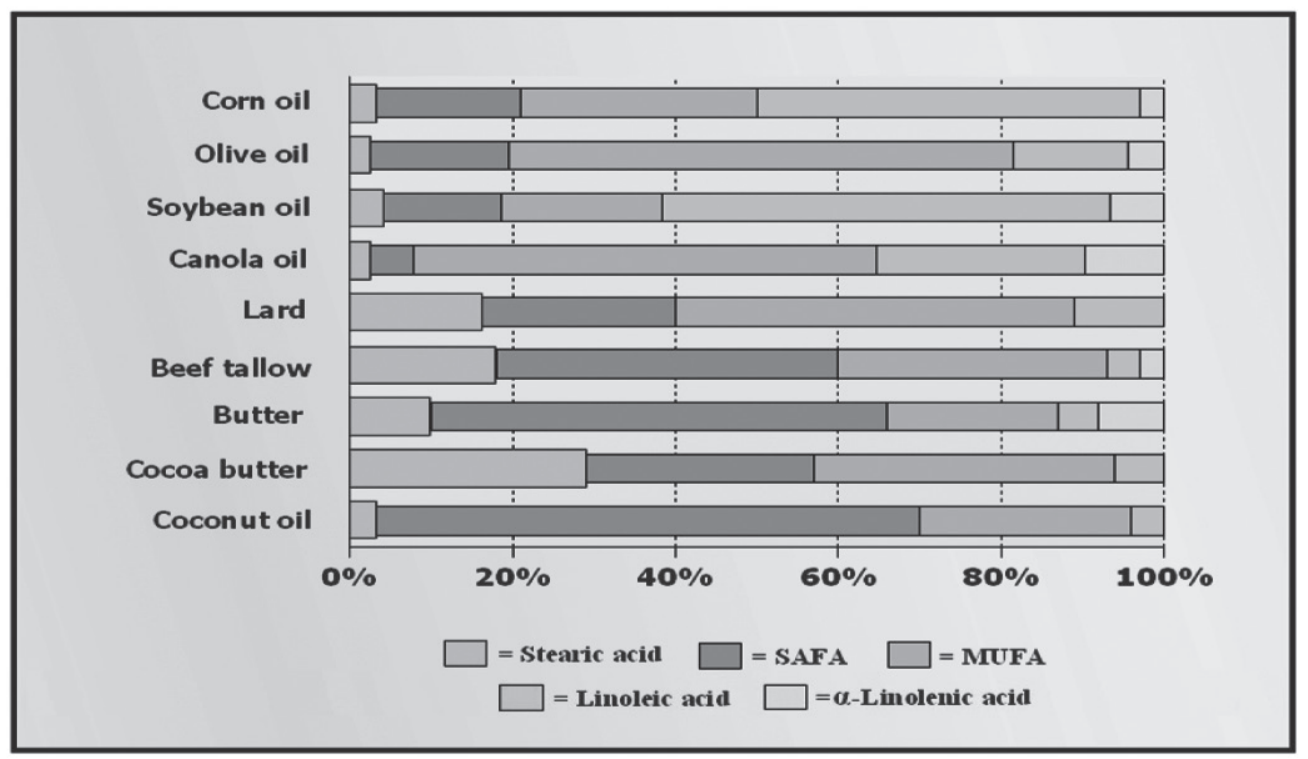

Figure 1

Common fatty acids in edible fats and oils. MUFA: monounsaturated fatty acids. Modified from Kris-Etherton et al., 2005. 
and alpha linolenic (C18:3) acids (Christie \& Moore, 1972). This special stereoisomerism has an important impact on the absorption degree of each fatty acid in the human small intestine (Kubow, 1996; Hunter, 2001).

Human digestive lipases, both lingual, gastric, as well as pancreatic, have special specificity to hydrolyze the sn-1 and sn-3 positions of dietary triglycerides (Bracco, 1994; Hunter, 2001), in such a way that less than $20 \%$ of the triglycerides are totally hydrolyzed into free fatty acids and glycerol (Mu \& Hǿy, 2004). In this way, the main products of triglyceride intestinal hydrolysis are monoglycerides with sn-2 sterified fatty acids, and fatty acids released from the sn-1 and $s n-3$ positions. This is how STA, released from both animal and vegetal fats, will be present in the small intestine lumen, after the digestive process, primarily in a free form and secondarily as part of $s n-2$ monoglycerides (Kritchevsky, 1994; Hunter, 2001). When STA is located in the sn-2 position in the triglycerides it is well absorbed, but when found in the sn-1 or sn-3 positions it is only partially absorbed, ranging from 37 to $55 \%$ (Mattson et al., 1979).

\section{STA DIGESTION AND ABSORPTION}

Studies have demonstrated that, comparatively, STA is absorbed in a lower proportion than other SAFAs such as lauric, myristic and palmitic, and even MUFA, as oleic, or type C18:1 TFA isomers (Baer, 2003). The general conclusion is that STA is less absorbed than other dietary SAFAs, therefore its plasmatic concentration would be lower when compared with the ones obtained with similar amounts of other SAFAs (Kris-Etherton et al., 1997; Kris-Etherton et al., 2005). The reason for the reduction in the presence of STA at plasmatic level, compared with equivalent amounts of other SAFAs, is not yet fully known (German \& Dillard, 2004). It has been postulated that due to its relatively high melting point $\left(70^{\circ} \mathrm{C}\right)$, when released into the intestinal lumen under the effect of enzymatic hydrolysis, it would form calcium and/or magnesium insoluble salts, which would be eliminated through depositions (Mattson et al., 1979). Other researchers have also postulated that a certain percentage of absorbed STA would be turned into oleic acid through intestinal cell desaturation (Garg, 1992). This transformation has been estimated to be around $9 \%$ and $14 \%$ (Rhee et al., 1997). Whatever the reason might be, the point is that STA absorption is lower than that of SAFA with fewer carbon atoms (Kris-Etherton et al., 2005), particularly when found in sn-1 and sn-3 positions. Nevertheless, the lower absorption is not exclusive when STA takes up these triglyceride positions. SALATRIM is a structured lipid which contains long chain SAFAs, mainly STA, in sn-1 and sn-3 positions, and short chain fatty acids (acetic, propionic and/or butyric) in the $s n-2$ position. For this reason, SALATRIM is a proved low digestibility fat and its consumption produces the elimination of high quantities of STA through depositions (Finley et al., 1994). This characteristic has made it a popular low calorie fat. However, when SALATRIM is previously randomized through interesterification, the molecule loses symmetry and thus leaves a significant proportion of STA in the $s-2$ position. When the resulting products effect is tested, the fatty acid also shows low absorption (Berry \& Sanders, 2005). Hence, it is suggested that regardless of the position STA occupies in triglycerides (sn-1, sn-2 or sn-3), its intestinal absorption is always low (Berry \& Sanders, 2005; Berry et al., 2007).

It has been proposed that STA would be a bad substrate for acyl-cholesterol-acyl-transferase enzyme (ACAT) which is responsible for cholesterol re-esterification in the intestine (Daumerie et al., 1992). If cholesterol is not re-esterified into intestine cells, it is again transported to the intestinal lumen and eliminated with faeces (Rodríguez-Meléndez et al., 2006). It has also been proposed that STA would enhance cholesterol hepatic excretion through bile (Imaizumi et al., 1993), although this increase does not occur experimentally in hamsters (Hassel et al., 1997). Moreover, it has been demonstrated that STA inhibits the expression of the Nieman-Pick C1 L1 transporter (NPC1L1) in the $\mathrm{FH} 74$ cell line of intestinal cells (Hunter 2001). This transporter is responsible for carrying cholesterol from intestinal lumen to the enterocyte (Rodríguez-Meléndez et al., 2006). As a result of both mechanisms, lower cholesterol absorption at the intestinal level would be produced due to the effect of STA.

\subsection{Effects on plasmatic lipids}

Predictive equations for the differential effects of fatty acids on plasmatic lipids developed independently by Keys et al., (1965) and Hegsted et al., (1965) several decades ago, demonstrated the hypercholesterolemic effect of SAFA and its consequent increase in cardiovascular risk. However, when these equations were applied to STA, the fatty acid appeared with a "neutral" effect on plasmatic cholesterol levels. More complex mathematical equations, like the one developed by Mensink y Katan (1992), demonstrated the neutral effect of the fatty acid, not only on total cholesterol, but also on LDL- and HDL- cholesterol levels. Similar results were obtained by $\mathrm{Yu}$ et al. (1995), who developed new predictive formulae starting from regression studies, concluding that STA has a neutral effect on the lipid profile in men as well as in women. Moreover, when comparing its effect with lauric, palmitic or myristic acid, STA shows a neutral or slightly positive effect on plasmatic lipids (Hunter, 2001). A meta-analysis carried out by Mensink et al. (2003) on 60 controlled clinical trials compared the effect of SAFA on the modification of plasmatic lipids with respect to their substitution by carbohydrates in the diet. It was demonstrated that STA reduces cholesterol plasmatic levels and 
the relationship between total cholesterol and HDLcholesterol. The modification of both parameters is a positive marker for reduced cardiovascular risk. Similar studies have demonstrated that dietary STA, contributing from $9 \%$ to $40 \%$ of the total energy, does not modify total plasmatic cholesterol, and even in some cases it is reduced (Aro et al., 1997; Nestel et al., 1998; Snook et al., 1999). A more recent study by Thijssen \& Mensink (2005), showed that diets with $7 \%$ of STA produce changes in the lipid profile similar to those yielded by a diet having an equal amount of oleic or linoleic acid. In this work, a detailed evaluation on the lipoprotein profile was carried out by Nuclear Magnetic Resonance (NMR), showing that the three fatty acids have similar effects on total and LDLcholesterol reduction. Surprisingly for researchers, STA also increased HDL-cholesterol, an effect which has been previously observed only with oleic and linoleic acids. Another remarkable observation on Thijssen \& Mensink's work (2005) is that STA does not modify LDL size, that is, it does not increase smaller sized LDLs, which are considered more atherogenic than larger sized LDLs (Gardner et al., 1996). The experimental protocol used by Thijssen \& Mensink involved fats only from natural origin, where STA mainly occupies sn-1 and sn3 positions. A more recent work by Sundran et al (2007), demonstrates that an interesterified fat, with a high proportion of STA (40\%), negatively modifies the lipid profile, also increasing the plasmatic glucose levels. However, an analysis on the fatty acid triglyceride sterochemistry, shows that $15 \%$ of STA is in the sn-2 position. This result emphasizes the concept that the beneficial effects derived from STA are obtained when it takes up sn-1 and sn-3 of triglyceride positions. An equal effect to other saturated fatty acids is observed when it is located in the sn-2 position (Sundran et al., 2007).

Apolipoproteins make up the protein part of lipoproteins and enable the selective recognition of these proteins by different tissues. B-100 apolipoprotein (ApoB-100) is only present in VLDL and LDL which derive from VLDL. In this way, high levels of ApoB-100 are indicative of an active triglyceride (by VLDL) and cholesterol (by LDL) transport. On the contrary, low ApoB-100 plasmatic levels mean low VLDL and LDL concentrations. Two studies demonstrated that when STA provides either $9.3 \%$ or $36 \%$ of the energy, a reduction in ApoB-100 from $10 \%$ to $18 \%$ is produced (Tholstrup et al., 1994; Aro et al., 1997). However, the latter study also demonstrated that STA increases lipoprotein (a) plasmatic levels. This type of lipoprotein has similar characteristics to LDL, which is related to a higher atherogenicity and considered an emerging marker of cardiovascular disease (Clevidence et al., 1997). This effect has also been shown by a study on fasting (Tholstrup et al., 1995), and in post-prandial conditions (Tholstrup \& Samman, 2004). The available data concerning the changes in lipoprotein (a) concentration with dietary TFA are limited, and further studies concerning a relationship between TFA and lipoprotein (a) are needed.

\subsection{STA, activation of thrombogenic factors and blood pressure}

The activation of thrombogenic factors due to post-prandial lipemia effect has been associated with an increase in cardiovascular risk. A meal rich in STA increases lipemia, but to lower levels than lipemia resulting from taking oleic and elaidic acids (Sanders et al., 2000), or palmitic acid (Mennen et al., 1998), probably due to the low absorption effect of STA already discussed. The increase in postprandial lipemia raised the concentration of Factor VIlc activated form, a coagulation factor dependent on vitamin K. Fatty acids in general increase the activation of this Factor (Mitropoulos et al., 1994; Mennen et al., 1998). However, comparatively, STA produces a lower activation of this factor than oleic acid, as observed by Tholstrup et al. (1994) and later confirmed by Sanders et al. (2000); also lower than palmitic acid (Mennen et al., 1998).

The effect of STA on hemodynamics is still not clear and in some cases is controversial. Multiple intervention studies have demonstrated an inverse correlation between cholesterol plasmatic levels and STA, and the diastolic pressure measured in middle-aged individuals with high cardiovascular disease risk (Simon et al., 1996). However, when this measurement is made on healthy individuals, both plasmatic cholesterol as well as STA levels significantly increases left ventricular diastolic pressure (Steer et al., 2002). Controlled clinical trials demonstrate that diets with 8 to $13 \%$ of the total energy as STA, have no effect on vascular pressure measured in diabetic patients (Storm et al., 1997), or in men and women with vascular pressure at normal ranges (Zock et al., 1993). This information is important because it corresponds to studies with standard STA intakes.

Finally, there is little evidence on the effect of STA on molecular markers of inflammation, such as cytokines (interleukine-6, for example), adhesion molecules (such as selectins), or acute-phase expression proteins (such as C-reactive protein), which are important to predict cardiovascular disease (Blake \& Ridker, 2002). STA does not modify plasmatic levels of these molecular markers if the diet imparts $11 \%$ of its energy as STA (Baer et al., 2004), although it does increase fibrinogen levels when taking in $11 \%$ of the energy as STA (Baer et al, 2004). Nevertheless, Kris-Eherton et al (2005) do not consider this last point relevant due to the fact that the average consumption STA is lower than $3 \%$ of the energy (Ervin et al., 2004). Thijssen et al. (2005) demonstrated that diets with $7 \%$ of the energy as STA, which is significantly higher than average consumption (3\%), do not affect blood platelet aggregation. Therefore, researchers conclude that STA would not have thrombogenic effects, making it comparable to oleic or linoleic acid. 


\section{FINAL CONSIDERATIONS}

There is a clear need to alert oil seed producers that there will likely be a requirement for an increased supply of substitute oils in order to replace TFA and that this represents an opportunity to expand or develop new oil seed varieties. The results of scientific updates should provide the evidence and scientific bases to promote discussions between the international scientific community related to nutrition and health as well as to agriculturalists and the food production industry, relevant health professionals, national and international food regulatory agencies, civil society, and the private sector in order to achieve this goal.

Available information, derived from experimental, clinical and epidemiological research, enables us to confirm with reasonable evidence, that when STA is consumed in less than $7 \%$ of the total energy, lipid profile, thrombotic factors, hemodynamic and cardiovascular risk molecular markers are not modified (Kris-Etherton et al., 2005; Hunter et al., 2010). This aspect distinguishes STA from other SAFAs present in diets, such as palmitic, lauric and myristic, while it ranks among MUFAs, such as oleic acid, or polyunsaturated acids, such as linoleic acid. The reason for this "neutral" effect is still unclear, and could be assigned to different factors: a lower absorption and higher excretion in the intestinal lumen when located in the sn-1 and sn-3 positions of dietary triglycerides; a partial conversion into oleic acid through intestine cell desaturation; to an inhibitory effect on ApoB-100 synthesis; or to other factors not yet identified. Everything focuses on the fact that fats with a high proportion of STA in the sn-1 and sn-3 positions could be very good substitutes for hydrogenated fats with high contents of TFA isomers. It should be pointed out that the neutral effect on cardiovascular diseases attributed to chocolate consumption would be due, in some degree, to a high proportion of STA in the sn-1 and sn-3 positions found in cocoa butter, together with its high cytoprotective flavonoids content (Ding et al., 2006). Oils with high STA content in the sn1 and sn-3 triglyceride position for frying use, are high temperature resistant due to their saturated characteristics. These could be an adequate substitute for partially hydrogenated fats with high contents of TFA isomers, which are nowadays used in the food industry and mainly for frying processes in fast food chains (DiRienzo et al., 2008). In summary, we conclude that STA may be a reasonable substitute for TFA and also for cholesterol-raising SAFAs for solid fat applications, such as baked goods, shortenings, spreads, and margarines.

\section{REFERENCES}

Allison DB, Egan SK, Barraj LM, Caughman C, Infante M, Heimbach JT. 1999. Estimated intakes of trans fatty acids and other fatty acids in the US population. J. Am. Diet. Assoc. 99, 166-174.
Aro A, Jauhiainen M, Partenen R, Salminen L, Mutanen M. 1997. Stearic acid, trans fatty acids, and dairy fat: effects on serum and lipoprotein lipids, apolipoproteins, lipoprotein(a), and lipid transfer protein in healthy subjects. Am. J. Clin. Nutr. 65, 1419-1426.

Aro A. 2005. The scientific basis of TFA regulationsis it sufficient? A personal view. First International Symposium on Trans fatty Acids and Health. Rungstedgaard, Denmark, September 11-13, Abstract.

Ascherio A, Rimm EB, Giovannucci EL, Spiegelman D, Stampfer M, Willett WC. 1996. Dietary fats and risk of coronary heart disease in men: cohort follow up study in the United States. Brit. Med. J. 313, 84-90.

Baer DJ, Judd JT, Kris-Etherton PM, Zhao G, Emken EA. 2003. Stearic acid absorption and its metabolizable energy value are minimally lower than those of other fatty acids in healthy men fed mixed diets. J. Nutr. 133, 4129-4134.

Baer DJ, Judd J, Clevidence B, Tracy R. 2004. Dietary fatty acids affect plasma markers of inflammation in healthy men fed controlled diets: a randomized crossover study. Am. J. Clin. Nutr. 79, 969-973.

Berry SE, Sanders TA. 2005. Influence of triacylglyceride structure of stearic acid-rich fats on postprandial lipaemia. Proc. Nutr. Soc. 64, 205-212.

Berry SE, Miller GJ, Sanders TA. 2007. The solid fat content of stearic acid-rich fats determines their postprandial effects. Am. J. Clin. Nutr. 85, 1486-1494.

Blake GJ, Ridker PM. 2002. Inflammatory biomarkers and cardiovascular risk prediction. J. Intern. Med. 252, 283-294.

Bracco U. 1994. Effect of triglyceride structure on fat absorption. Am. J. Clin. Nutr. 60, 1002S-1009S.

Carroll KK. 1958. Digestibility of individual fatty acids in the rat. J. Nutr. 64, 399-410.

Christie WW, Moore JH. 1972. The structure of adipose tissue and heart muscle triglycerides in the domestic chicken (Gallus gallus). J. Sci. Food Agric. 23, 73-77.

Clevidence BA, Judd JT, Schaefer EJ. 1997. Plasma lipoprotein (a) levels in men and women consuming diets enriched in saturated cis or transmonounsaturated fatty acids. Arterioescler. Thromb. Vasc. Biol. 17, 1657-1661.

Craig-Schmidt M. 2006. World-wide Consumption of trans fatty acids. Atherosclerosis (suppl) 7, 1-4.

Daumerie CM, Woollett LA, Dietschy JM. 1992. Fatty acids regulate hepatic low density lipoprotein receptor activity through redistribution of intracellular cholesterol pool. Proc. Natl. Acad. Sci. USA. 89, 10797-10801.

Ding E, Hutfless S, Ding X, Girotra S. 2006. Chocolate and prevention of cardiovascular disease: a systematic review. Nutrition \& Metabolism, 3, 2-14.

Di Rienzo MA, Lemke SL, Petersen BJ, Smith KM. 2008. Effect of substitution of high stearic acid low linolenic acid soybean oil for hydrogenated soybean oil on fatty acid intake. Lipids 43, 451-456.

Eckel RH, Borra S, Lichtenstein AH, Yin-Piazza SY. 2007. Understanding the complexity of trans fatty acid reduction in the American diet. Circulation 115, 2231-2246.

Ervin RB, Wright JD, Wang CY, Kennedy-Stephenson J. 2004. Dietary intake of fats and fatty acids for the United States population: 1999-2000. Adv. Data (November 8), 1-6.

Finley J, Klemann L, Levielle G, Otterburn M, Walchak C. 1994. Caloric availability of SALATRIM in rats and humans. J. Agric. Food Chem. 42, 495-499. 
Gardner CD, Fortmann SP, Krauss RM. 1996. Association of small low density lipoproteins particles with the incidence of coronary artery disease in men and women. Jama 276, 875-881.

Garg ML. 1992. Stearic Acid Desaturation and incorporation into murine peritoneal macrophage lipids. J. Clin. Biochem. Nutr. 13, 169-178.

German JB, Dillard CJ. 2004. Saturated fats: what dietary intake?. Am. J. Clin. Nutr. 80, 550-559.

Hassel CA, Mensing E, Gallaher D. 1997. Dietary stearic acid reduces plasma and hepatic cholesterol concentration without increasing bile acid excretion in cholesterol-fed hamsters. J. Nutr. 127, 1148-1155

Hegsted DM, McGandy RB, Myers ML, Stare FJ. 1965. Quantitative effects of dietary fat on serum cholesterol in man. Am. J. Clin. Nutr. 17, 281-295.

Hu F, Stampfer M, Manson J, Rimm E, Colditz G, Rosner B, Hennekens C, Willett W. 1997. Dietary fat intake and the risk of coronary heart disease in women. $N$. Engl. J. Med. 337, 1491-1499.

Hunter JE. 2001. Studies on effects of dietary fatty acids as related to their position on triglycerides. Lipids 36 , 655-668.

Hunter JE. 2006. Dietary trans fatty acids: a review of recent human studies and food industry responses. Lipids 41, 967-992.

Hunter JE, Zhang J, Kris-Etherton P. 2010. Cardiovascular disease risk of dietary stearic acid compared with trans, other saturated, and unsaturated fatty acids: a systemic review. Am. J. Clin. Nutr. 91, 46-63.

Hutshof K, Van Erp-Baart MA, Anttolainen M. 1999 Intake of fatty acids in western Europe with emphasis on trans fatty acids: the TRANSFAIR study. Eur. J. Clin. Nutr. 53, 143-57.

Imaizumi K, Abe K, Kuroiwa C, Sugano M. 1993. Fat containing stearic acid increases fecal neutral steroid excretion and catabolism without affecting plasma cholesterol concentration in hamsters fed a cholesterol-containing diet. J. Nutr. 123, 1683-1702.

Judd JT, Clevidence DJ, Kris-Etherton P, Muesing R A, Iwane N. 2002. Dietary cis and trans monounsaturated and saturated fatty acids and plasma lipids and lipoprotein in men. Lipids, 37, 123-131.

Keys A, Anderson JT, Grande F. 1965. Serum cholesterol response to changes in the diet IV. Particular saturated fatty acids in the diet. Metabolism 14, 776-787.

Korver O, Katan M. 2006. The elimination of trans fats from spreads: how science helped to turn an industry around. Nutr. Rev. 64, 275-279.

Kris-Etherton P, Yu S. 1997. Individual fatty acid effects on plasma lipids and lipoproteins: human studies. Am. J. Clin. Nutr. 65, 1628S-1644S.

Kris-Etherton PM, Griel AE, Psota TL, Gebauer S K, Zhang J, Etherton TD. 2005. Dietary stearic acid and risk of cardiovascular disease: intake, sources, digestion, and absorption. Lipids, 40, 1193-1200.

Kritchevsky D. 1994. Stearic acid and atherogenesis: history. Am. J. Clin. Nutr. 60, 997S-1001S.

Kromhout D, Menotti A, Bloemberg B. 1995. Dietary saturated and trans fatty acids and cholesterol and 25-year mortality from coronary heart disease: The Seven Countries Study. Prev. Med. 24, 308-315.

Kubow S. 1996. The influence of positional distribution of fatty acids in native, interesterified and structurespecific lipids on lipoprotein metabolism and atherogenesis. J. Nutr. Biochem. 7, 530-541.

Larqué E, Zamora S, Gil A. 2001. Dietary trans fatty acids in early life: a review. Early Human Develop. 65, S31-S41.
Leth T, Bysted A, Erendah-Mikkelsen A. 2005. The effect of the regulation on trans fatty acid content in danish food. First International Symposium on trans fatty acids and health. Rungstedgaard, Denmark, September 11-13, Abstract.

Mattson FH, Volpenhein RA. 1964. The digestion and absorption of triglycerides. J. Biol. Chem. 239, 27722777.

Mattson FH, Nolen GA, Webb MR. 1979. The absorbability by rats of various triglycerides of stearic and oleic acid and the effect of dietary calcium and magnesium. J. Nutr. 109, 1682-1687.

Mennen L, de Maat M, Meijer G, Zock P, Grobbee D, Kok F, Kluft C, Schouten E. 1998. Factor VIla response to a fat-rich meal does not depend on fatty acid composition: a randomized trial. Arterioscler. Thromb. Vasc. Biol. 18, 599-603.

Mensink RP, Katan MB. 1992. Effect of dietary fatty acids on serum lipids and lipoproteins. A Meta-analysis of 27 Trials. Arterioscler. Thromb. 12, 911-919.

Mensink RP, Zock PL, Kester AD, Katan MB. 2003. Effects of dietary fatty acids and carbohydrates on the ratio of serum total to HDL-cholesterol and on serum lipids and apolipoproteins: a meta-analysis of 60 controlled trials. Am. J. Clin. Nutr. 77, 1146-1155.

Mitropoulos K, Miller G, Martin J, Reeves B, Cooper J. 1994. Dietary fat induces changes in factor VII coagulant activity through effects on plasma free stearic acid concentrations. Atheroscler. Thromb. 14, 214-222.

Morin O. 2007. Huiles végétales et margarines : évolution de la qualité - Les solutions technologiques à la réduction des acides gras trans. Cah. Nutr. Diét., 42 , 5, A paraître.

Mozaffarian D, Katan M, Ascherio A, Stampfer M, Willett W. 2006. Trans fatty acids and cardiovascular disease. New Engl. J. Med. 354, 1601-1613.

Mozaffarian D, Aro A, Willett W. 2009. Health effects of trans-fatty acids: experimental and observational evidence. Europ. J. Clin. Nutr. 63, S5-S21.

Mozaffarian D, Clarke R. 2009. Quantitative effects on cardiovascular risk factors and coronary heart disease risk of replacing partially hydrogenated vegetable oils with other fats and oils. Eur. J. Clin. Nutr. 63, S22-S33.

Mu H, Hǿy C. 2004. The digestion of dietary triacylglycerols. Prog. Lipid. Res. 43, 105-133.

Nestel PJ, Pomeroy S, Kay S, Sasahara T, Yamashita T. 1998. Effect of a stearic acid-rich, structured triacylglycerol on plasma lipids concentrations. Am. J. Clin. Nutr. 68, 1196-1201.

Rhee SK, Adlof RO, Ciszek A, Brenna JT. 1997. Desaturation and interconversion of dietary stearic and palmitic acid in human plasma and lipoproteins. Am. J. Clin. Nutr. 65, 451-458.

Rodríguez-Meléndez R, Rasmussen HE, Lee JY, Carr TP. 2006. NPC1L1 gene expression is downregulated by stearic acid in CCL-241 cells. Faseb $\mathrm{J}$. 20, 138-145.

Sanders T, de Grassi T, Miller G, Morrissey J. 2000. Influence of fatty acid chain-lenght and cis/trans isomerization on postprandial lipemia and Factor VII in healthy subjects. Atherosclerosis 149, 413-420.

Salmeron J, Hu FB, Manson JE, Stampfer MJ, Colditz GA, Rimm E B, Willett W. 2001. Dietary fat intake and risk of type 2 diabetes in women. Am. J. Clin. Nutr. 73, 1019-1026.

Saravanan N, Haseeb A, Ehteham NZ, Ghafoorunissa X. 2005. Differential effects of dietary saturated and 
trans fatty acids on expression of genes associated with insulin sensitivity in rat adipose tissue. Eur. J. Endocrinol. 153, 159-165.

Simon J, Fong J, Bernert J. 1996. Serum fatty acids and blood pressure. Hypertension 27, 303-307.

Snook J-T, Park S, Williams G, Tsai YH, Lee, N. 1999. Effect of synthetic triglycerides of myristic, palmitic, and stearic acid on serum lipoprotein metabolism. Eur. J. Clin. Nutr. 53, 597-605.

Steer P, Millgard J, Sarabi D, Basu S, Vessby B, Kahan T, Edner M, Lind L. 2002. Cardiac and vascular structure and function are related to lipid peroxidation and metabolism. Lipids 37, 231-236.

Stender S, Dyerberg J, Astrup A. 2006. High levels of trans fat in popular fast foods. N. Engl. J. Med. 354, 1650-1652.

Storm H, Thomsen C, Pedersen E, Rassmussen O, Christiansen C, Hermansen K. 1997. Comparison of a carbohydrate-rich diet and diets rich in stearic or palmitic acid in NIDDM patients. Effects on lipids, glycemic control, and diurnal blood pressure. Diabetes Care 20, 1807-1813.

Sundran K, Ismail A, Hayes K, Jeyemalar R, Pathmanathan R. 1997. Trans (elaidic) fatty acids adversely affect the lipoprotein profile relative to specific saturated fatty acids in humans. J. Nutr. 127, 514S-520S.

Sundran K, Karupaih T, Hayes K. 2007. Stearic acid-rich interesterified fat and trans-rich fat raise the LDL/HDL ratio and plasma glucose relative to palm olein in humans. Nutrition \& Metabolism 4, 3-15.

Tanasescu M, Cho E, Manson JE, Hu FB. 2004. Dietary fat and colesterol and the risk of cardiovascular disease among women with type 2 diabetes. Am. J. Clin. Nutr. 79, 999-1005.

Tarragó-Trani T, Phillips K, Lemar L, Holden J. 2006. New existing oils and fats used in products with reduced trans-fatty acid content. J. Am. Diet Assoc. 106, 867-880.

Thijssen MA, Mensink R P. 2005. Small differences in the effects of stearic acid, oleic acid, and linoleic acid on the serum lipoprotein profile of humans. Am. J. Clin. Nutr. 82, 510-516.

Thijssen MA, Hornstra G, Mensink R. 2005. Stearic, oleic, and linoleic acids have comparable effects on markers of trombotic tendency in healthy human subjects. J. Nutr. 135, 2805-2811.
Tholstrup T, Marckmann P, Jespersen J, Sandtrom B. 1994. Fat high in stearic acid favorably affects blood lipids and Factor II coagulant activity in comparison with fats high in palmitic acid or high in myristic and lauric acids. Am. J. Clin. Nutr. 59, 371-377.

Tholstrup T, Marckmann P, Vessby B, Sandstrom B. 1995. Effects of fats high in individual saturated fatty acids on plasma lipoprotein(a) levels in young healthy men. J. Lipid Res. 36, 1447-1452.

Tholstrup T, Samman S. 2004. Postprandial lipoprotein(a) is affected differently by specific individual dietary fatty acids in healthy young men. J. Nutr. 134, 25502555.

Uauy R, Aro A, Clarke R, Ghafoorunissa X, L'Abbé M, Mozaffarian D, Skeaff CM, Stender S, Tavella A. 2009. WHO Scientific update on trans fatty acids: summary and conclusions. Eur. J. Clin. Nutr. 63, S68-S75.

U.S. Food and Drug Administration and Center for Food Safety and Applied Nutrition 2003. Food Labelling: Trans fatty acids in nutrition labeling, nutrient content claims, and health claims. Federal Register 68, 41434-41506.

Valenzuela A, Morgado N. 1999. Trans fatty acid isomers in human health and in the food industry. Biol. Res. 32, 273-287.

Valenzuela A. 2008. Trans fatty acid consumption in Latin America. In "Healthy oils and the elimination of industrially produced trans fatty acids in the Americas" Pan American Health Organization (PAHO) Document, Washington DC, pp 15-27.

Valenzuela A. 2008a. Ácidos grasos con isomería trans II. Situación de consumo en Latinoamérica y alternativas para su sustitución. Rev. Chil. Nutr. 35, 172-180.

Yu S, Derr J, Etherton T, Kris-Etherton P. 1995. Plasma cholesterol-predictive equations demonstrate that stearic acid is neutral and monounsaturated fatty acids are hypocholesterolemics. Am. J. Clin. Nutr. 61, 1129-1139.

Zock P, Blijlevens R, de Vries J, Katan M. 1993. Effects of stearic acid and trans fatty acids versus linoleic acid on blood pressure in normotensive women and men. Eur. J. Clin. Nutr. 47, 437-444.

Recibido: $16 / 3 / 10$ Aceptado: 25/5/10 